\title{
Sociodemographic Factors to Dengue Hemmorrhagic Fever Case in Indonesia
}

\author{
Faktor-faktor Sosiodemografi terhadap Kasus Demam Berdarah di \\ Indonesia
}

\author{
Desy Nuryunarsih
}

\author{
College of Human Medicine, Public Health, Michigan State University, USA
}

\begin{abstract}
Dengue hemorrhagic fever (DHF) is a leading cause of hospitalization and death among children. Indonesia is one of those countries categorized by World Health Organization (WHO) as hyperendemicity with four serotypes circulating in urban area. Sociodemographic factors are considered as factors affecting DHF in Indonesia. This study used secondary data downloaded from Province Health Database 2010 of Health Ministry Republic of Indonesia to determine correlation between three sociodemographic factors to DHF incidence. This study used quantitative descriptive correlational methods. Results showed the selected two sociodemographic factors had a linear impact on DHF incidence. Multiple regression multivariate analysis showed least correlation between DHF incidence and three selected sociodemographic factors. However, the univariate regression analysis showed that population density and poverty had significant correlation to DHF, respectively the population density $r(4)=0.843$, $p$ value $<0.05$ and poverty $r(4)=0.897$, $p$ value $<0.05$. Variable of age under 15 years old did not have any positive correlation to DHF. It is expected this study may have contribution to DHF prevention programs by helping public health practitioners develop more strategies with respect to the sociodemographic factors.
\end{abstract}

Keywords: Dengue hemorrhagic fever, public health, sociodemographic factors

\footnotetext{
Abstrak

Demam berdarah dengue (DBD) adalah penyebab utama rawat inap dan kematian pada anak-anak. Indonesia adalah salah satu negara yang oleh WHO dikategorikan hyperendemicity dengan empat serotipe virus tersebar di daerah perkotaan. Faktor sosiodemografi dianggap sebagai faktor pendukung terjadinya DBD di Indonesia. Studi ini menggunakan data sekunder yang diunduh dari Basis Data Kesehatan Provinsi tahun 2010 Kementerian Kesehatan Republik Indonesia untuk menentukan korelasi antara ketiga faktor sosiodemografi dengan insiden DBD. Penelitian ini menggunakan
}

metode kuantitatif deskripsi korelasi. Hasil penelitian menunjukkan bahwa dua faktor sosiodemografi terpilih memiliki korelasi linier dengan insiden DBD. Analisa regresi multivariat menunjukkan kecilnya korelasi antara insiden DBD dengan sekaligus tiga faktor sosiodemografi terpilih. Akan tetapi, hasil perhitungan analisa regresi univariat menunjukkan bahwa kepadatan penduduk dan kemiskinan memiliki korelasi yang signifikan terhadap DBD. Kepadatan penduduk $r(4)=0,843$, nilai $p<0,05$, sedangkan kemiskinan $r(4)=0,897$, nilai $p<0,05$. Variabel usia di bawah 15 tahun tidak memiliki korelasi positif terhadap insiden DBD. Diharapkan penelitian ini dapat memiliki kontribusi terhadap program pencegahan DBD dengan cara membantu praktisi kesehatan masyarakat mengembangkan strategi pencegahan DBD, terutama yang berhubungan dengan faktor sosiodemografi.

Kata kunci: Demam berdarah dengue, kesehatan masyarakat, faktor sosiodemografi

\section{Introduction}

Dengue fever and dengue hemorrhagic fever (DHF) are viral diseases transmitted by Aedes mosquitoes, usually Aedes aegypti. ${ }^{1}$ DHF is mostly found in tropical areas around the world, such as Southeast Asia, tropical regions of Africa, and South America. ${ }^{2}$ In Indonesia, dengue is a cyclical disease with peak incidence occurs during the wet season (January - August). The disease is a leading cause of hospitalization and death among young in Indonesia. $3-5$

Based on a report by Health Ministry Republic of Indonesia, over one thousand people are estimated to have died during the DHF epidemic from 2009 - 2011.

Korespondensi: Desy Nuryunarsih, College of Human Medicine Public Health Michigan State University, East Lansing, Michigan USA Al Hail South Way 2549 Muscat Oman, Phone: 1-517-355-1855,e-mail: nuryunar@msu.edu 
This places Indonesia the first in number of recorded DHF epidemic in Southeast Asia and the second in term of worldwide DHF case ranking. ${ }^{6}$

Eradication of DHF outbreak is critical as it is one of most common infectious diseases and an enormous public health issue in Indonesia. DHF has become an annual epidemic, claiming the lives of hundreds of Indonesians every year. The number of DHF cases is increasing, and the disease is spreading to new areas. These additional problems have occurred due to population mobility improvement, new settlements, improper mosquito net cleaning practices, climate change, etc. ${ }^{5,7}$

Dengue vaccines are viewed as a promising solution to control dengue. ${ }^{8}$ However, a vaccine does not yet exist to prevent infection with dengue virus. ${ }^{3}$ The reduction or prevention of dengue viral transmission depends on vector control of the Aedes aegypti mosquito and the secondary vector species, Aedes albopictus. ${ }^{9}$

Long-term changes in health management and adopting strong and integrative actions at various organizational levels are required to prevent and control dengue virus. ${ }^{10}$ The Indonesian government has established two levels of control namely the early warning system and mosquito vector control (The Law of Health Ministry No. 581/1992). Both vector controls are closely related to human health behavior. ${ }^{10}$

Controlling mosquito vectors by government action alone is not enough to reduce the number of DHF cases, so community participation is needed to ensure the success of prevention programs. ${ }^{11}$ Socioeconomic factors are thought to inhibit the effectivity of the government's vector control activities. The fundamental issue impeding the fight against dengue is the attitude of people who do not fully implement the clean and healthy lifestyle practices required to tackle dengue fever and other infectious diseases.

This raises an important question whether sociodemographic factors have correlation to incidence of DHF in Indonesia. Previous study showed that socioeconomic status (SES) and health were related, such positive health attitudes and behaviors were more prevalent among individuals of higher SES than among those of lower SES. ${ }^{4}$

Discussion of this study would focus more on relations between selected sociodemographic factors and the number of DHF incidence. Data on three sociodemographic variables from six major islands in Indonesia was analyzed to determine the correlation between sociodemographic factors and the incidence of DHF. The outcome of this study could have significant implications for the ongoing DHF prevention program, particularly for public health professionals. It may help those professionals prepare effective strategies to help the government establish a national plan and policy for
DHF prevention in particular related to sociodemographic factors.

Indonesia is the largest archipelago in the world with 17,508 islands, 6,000 of which are inhabited. It is located in Southeast Asia between the Indian Ocean and the Pacific Ocean and spans a total area of 1,919,440 square kilometer (land $=1,826,440$ square kilometer and water $=93,000$ square kilometer). Indonesia has a number of natural resources, including petroleum, tin, natural gas, nickel, timber, bauxite, copper, fertile soils, coal, gold and silver. Various Indonesian islands periodically face natural disasters, such as floods, severe droughts, tsunamis, earthquakes, volcanoes, and forest fires. ${ }^{12}$

Indonesia has a tropical climate suitable for the growth of the dengue vector that transmits DHF disease. ${ }^{13}$ According to a report by Health Ministry, more than 71,668 people across Indonesia were infected with dengue fever, with the death toll exceeding 641 (mostly children) in 2014. ${ }^{14}$

DHF is still a big challenge for the Indonesian government, although programs to eradicate DHF disease have been in place for 41 years. There are still outbreaks in several areas in Indonesia each year. While the mortality rate of dengue is decreasing, the morbidity rate increases each year.

Data shows that DHF has spread to areas not previously affected by the disease due to improvements in transportation that have made it easier for people to travel from one area to another, including to and from dengue-endemic areas. Dengue is no longer a disease that primarily affects children as now adults and elderly population are also at risk. In the past, DHF was classified as a group B arthropod-borne virus (arbovirus). ${ }^{15} \mathrm{It}$ is now classified as a member of the genus Flavivirus, family Flaviviridae. Dengue virus has four serotypes: DEN-1, DEN-2, DEN-3 and DEN-4. A flavivirus is a virus with a diameter of 30 nautical mile, which consists of single-stranded RNA and has a molecular weight of 40 - 60 nautical mile. ${ }^{16}$

DHF is transmitted through the bite of Aedes aegyp$t i$, a mosquito with the black and white stripes on their body and legs. Usually, female mosquitoes are responsible for biting. While both female and male mosquitoes are attracted to the sweet scent of fruits and plants, female mosquitoes also need protein from blood to help their eggs develop. ${ }^{17}$

In Indonesia, serotype DEN-3 is dominant, and it is assumed this stereotype causes severe clinical manifestations in patients. ${ }^{18}$ Bylon, ${ }^{19}$ first reported an epidemic of dengue from Jakarta in 1779. DHF, the severe form of dengue infection, was recognized in Surabaya and Jakarta in 1988. Dengue fever was first recorded in 1968 in Surabaya, East Java. More than 50 cases were identified and more than half of the victims died of the 
disease ${ }^{20}$ Dengue disease is becoming hyper-endemic in Indonesia, meaning that DHF is constantly at a high incidence.

This hyper-endemic state is due to having multiple dengue virus serotypes circulating within a community and too many other factors that become obstacles to eradicate DHF in Indonesia. Some issues are lack of understanding of standardized procedures to handle DHF patients in several health centers and clinics, sometimes over-diagnosing the disease, not all healthcare providers or hospitals use KDRS/KD-DBD form (early vigilance of DHF form), the first step for widespread prevention.

The KDRS/KD-DBD form is completed by local healthcare providers and to collect information of DHF patients in their areas. The form is then sent to the local health agency. Indonesia is a tropical country with climates conducive for mosquito breeding, especially during rainy season.

Population awareness about environmental sanitation is also important to eliminate areas suitable for mosquito proliferation. Access to better healthcare in the early stages of DHF and increasing people's knowledge of DHF may reduce mortality caused by this disease to as low as $1 \% .10$

In the last 50 years, DHF cases have increased 30 fold and today, dengue has the highest incidence of any mosquito-borne viral disease in the world. An estimated 2.5 billion people live in over 100 endemic countries and areas where dengue viruses can be transmitted. Up to 50 million infections occur annually with 500,000 cases of DHF and 22,000 deaths, mainly among children. ${ }^{21}$

In Indonesia, the annual incidence of DHF is significant in many provinces. The largest number of cases were in 1998 and 2004 on which 79,480 people were infected by DHF and more than 800 people died from the disease. ${ }^{5}$ Some factors are known to be related to increased virus transmitting namely vector (usually Aedes aegypti), dengue virus, susceptible human host, and environment. ${ }^{3}$ There are four serotypes of dengue virus that circulate throughout and are widely spread in Indonesia. Female mosquitoes can lay up to 300 eggs at a time and normally lay eggs three times before they die.

Dengue viral infection is transmitted to humans through the bite of the Aedes aegypti mosquito. DHF is a severe form of dengue infection characterized by acute fever lasting two to seven days, thrombocytopenia, neutropenia, bleeding, headache, painful aching in the legs and joints, and significant changes to the reticuloendothelial system, such as enlargement of the lymph glands, liver and spleen. In later stages, DHF causes a skin rash caused by blood vessels leaking under the skin. ${ }^{22,23}$

Three main factors that play an important role in the transmission of dengue viral infection are a human as a host, the dengue virus as a causative agent, and the dengue mosquito as a vector. DHF has historically been highly correlated with human population growth. ${ }^{24} \mathrm{An}$ other important factor to consider is poverty and poor living conditions in rural communities, such as contaminated water supply and sanitation facilities, inability to own a healthy house and lack of health education. ${ }^{25}$

Currently, no drugs or vaccinations exist for the prevention of DHF infection. ${ }^{26}$ The prevention and control of this epidemic disease requires effective control of the vector Aedes aegypti. Early on, the Indonesian government employed "fire-fighting tactics" i.e, focal fogging around DHF-epidemic areas, combined with health education in specific areas. However, this strategy was counterproductive in preventing DHF. ${ }^{27,28}$ In 1985, the government switched from a mass larviciding method to selective larviciding. Larviciding is an ecologically safe method used to interrupt the development of larvae or pupa into adult mosquitoes with Tempo $1 \%$ SG at a dosage of one parts per million known as abates. In 1991, the government began applying insecticides weekly using the fogging method in endemic villages, however, no single tool or method is likely to be effective in controlling Aedes aegypti.

The government began organizing community involvement in 1995. All health centers were instructed to provide training and guidance to cadres, so that they would be equipped to conduct larval surveys every three months, selecting 100 houses at random in each village. Today, the Indonesian government seeks to control the vector Aedes aegypti by employing the following methods, such as the insecticide method with Malathion (an organophosphorus insecticide used for pediculicide) or with fogging and Tempos (larvacide). A non-insecticide method known as Menguras, Menutup, Mengubur (3M) program consists of cleaning and covering water containers, and burying any used stuff. 28

The most important member of the $3 \mathrm{M}$ program is the family welfare women's empowerment organization known as Pembinaan Kesejahteraan Keluarga (PKK). They conduct regular home visits to educate families on DHF prevention and examine all water containers for the presence of Aedes aegypti larvae, updating the KDRS/KD-DBD form report system within 24 hours to allow DHF prevention and spread to other areas. District health workers will conduct epidemiology checks within a 100 meter radius of the patient's house, then conduct larvae inspection. If it is determined that the area has few larvae-free zones, the health workers will immediately carry out fogging in that area. ${ }^{28}$

\section{Method}

This study used secondary data about DHF incidence per 1,000 people and density per square kilometer per 1,000 people drawn from the Province Health Database 
2010. The source of health data bank were from four main elements namely health facility, universal insurer (BPJS), Health Ministry as well as community (surveillance, survey, and registry). The data were collected on routine basis by data and information center known as Pusat Data dan Informasi (Pusdatin) at the Health Ministry of Republic of Indonesia. ${ }^{29}$

The health database collected detailed reliable information on demography, education, type of disease, healthcare, health professional and health facility. In acquiring the data set, the author utilized open source system managed by data bank of Pusdatin at Health Ministry. 30 Other variable data which were 15 year-old people per 1,000 people and poverty per 1,000 people data source was National Population Census 2010 undertaken by The Central Statistics Agency on 1 May 2010 to 31 May 2010 as the census covered 33 provinces and 497 districts/municipalities scattered all over Indonesia, employing about 650,000 enumerators and supervisors. ${ }^{31}$

Population census 2010 included variables namely maternal death, disability, sanitation, poverty, people school age, etc. To provide a visual representation, scatter diagram (Figure 1 - 3) used, scatter plots showed the general trends for all sociodemographic factors selected and DHF case data. Linear and multilinear regression techniques were used to determine the correlation between number of DHF cases and sociodemographic variables. The aim of the multilinear regression analysis in this study was to determine whether or not variables related to poverty, population density, and population under 15 years old influenced the incidence of DHF in Indonesia in 2010. Extracted data about sociodemographic factors and DHF cases was analyzed using XLSTAT-premium, data analysis toolpak. Pearson correlation was the appropriate correlation coefficient chosen to which paired variables were correlated possitive or negative.

\section{Variables of Study}

The study examined sociodemographic variables suspected to influence the increasing incidence of DHF. Data were collected from The Central Statistics Agency and health data bank. DHF incidence as a dependent variables and selected sociodemographic factors as independent variables (poverty, people under 15 years old and density per square kilometer).

\section{Results}

There were two pairs of variables that wise correlate, namely incidence of DHF (000) with poverty and density. However, there was least correlation between incidence of DHF and age under 15 years old.

From the figure above, there seemed to be no pattern

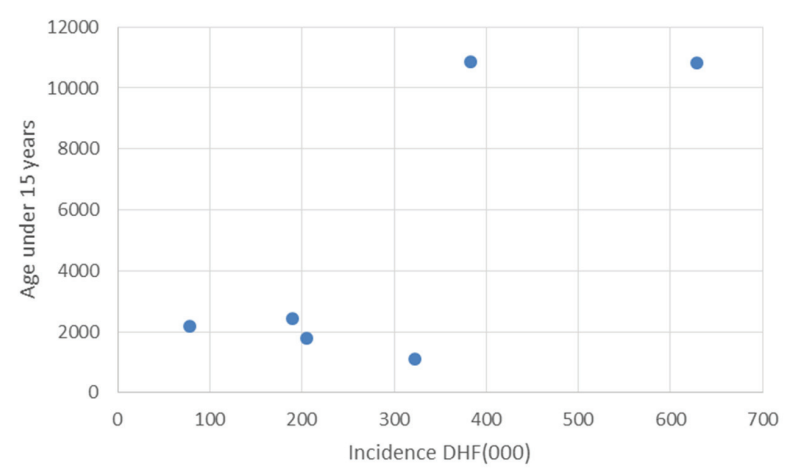

Figure 1. Scatter Plots of DHF Incidence (000) and Age under 15 Years Old

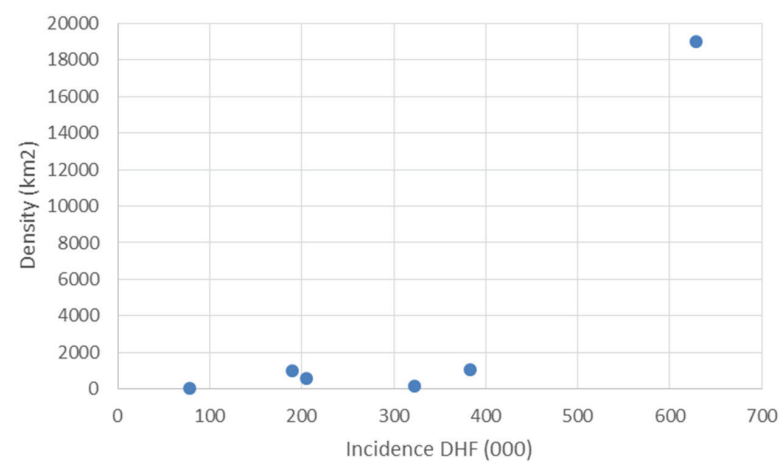

Figure 2. Scatter Plots of DHF Incidence (000) and Density $\left(\mathrm{km}^{2}\right)$

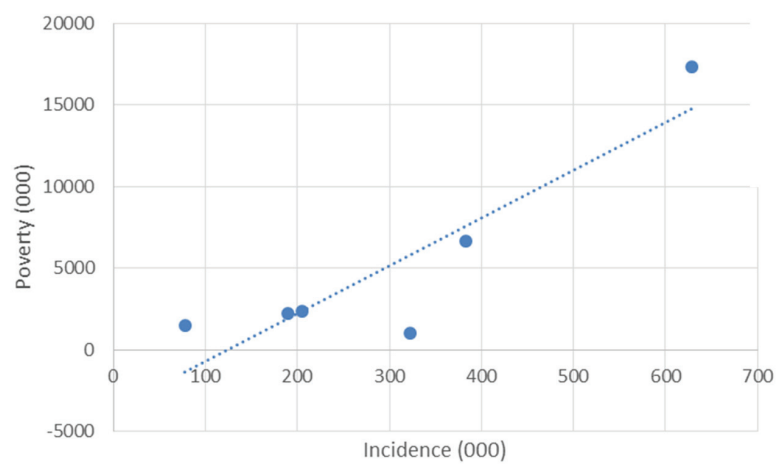

Figure 3. Scatter Plots of DHF Incidence and Poverty

and points look not scattered, there is no correlation (no apparent relation between age under 15 years old and DHF incidence). The figure showed constant correlation, although one outer was found at one point.

There seemed to be positive pattern and the points had linier trend, there was correlation between poverty and DHF incidence. To compare the strength of the interrelation between the three dimensions of selected sociodemographic factors, the author conducted linear univariate regression analysis (Table 1 ).

There was a significant positive correlation between the number of DHF cases and density $\left(\mathrm{km}^{2}\right)$, and poverty (000) approximately 84\%, 89\% (p value < 0.05 ). However, there was negative correlation between DHF 
Table 1. Estimates of Dependent and Independent Variable Relation

\begin{tabular}{lcccc}
\hline & Correlation coefficient (r) & Sum of Square & F test & p value \\
\hline Age under 15 years old (000) & 0.786 & 114673.5 & 6.4819 & 0.0635 \\
Density (km2) & 0.843 & 131899.2 & 9.8543 & 0.03487 \\
Poverty (000) & 0.897 & 185438.8 & 16.475 & 0.01536 \\
\hline
\end{tabular}

Table 2. Correlation of DHF Case and Three Variables (Poverty, Density, and Age under 15 Years Old)

\begin{tabular}{lcccc}
\hline & Coefficient correlation (r) & Sum of square & F test & p value \\
\hline Density, poverty and age under 15 years & 0.898 & 149794.8 & 2.8078 & 0.273 \\
\hline
\end{tabular}

incidence and age under 15 years old. Although coefficient correlation was very high, the $p$ value 0.06 was slightly higher ( $\mathrm{p}$ value $>0.05$ ).

Through the univariate linier regression calculation, the result showed the least correlation for the variable population under 15 years old and DHF incidence, signifying the more people under 15 years old in one area had no effect to the higher cases of DHF in that area. Highest correlation were shown for poverty and DHF incidence suggesting that the poorer population per square kilometer, the more number of DHF incidence, thus significant correlation also in the density and DHF cases, the higher population density in line with the high number of DHF incidence.

The multivariate relation between three selected sociodemographic factors (poverty, density, and age under 15 years old) and DHF cases was approximately $89.8 \%$ with $p$ value $=0.27(\mathrm{p}$ value $<0.1)($ Table 2$)$. All three independent variables selected (density, poverty, and age under 15 years old) were least correlated to the number of DHF cases, although it may not be appropriate to draw any conclusion based on this limited study.

\section{Discussion}

This study examined the correlation between selected sociodemographic factors and DHF cases and data drawn from National Population Census 2010 and data bank of Indonesian Health Ministry. This study revealed that no correlation was found between people under 15 years old and DHF cases. This may be as a result of the fact that adults are more likely to have clinical dengue than children. ${ }^{32,33}$

The multiple linear regression model predicts that any future population increase in population density increases the incidence of DHF. As explained by the study conducted in Vietnam, the density of people in between 3,000 to 7,000 people per square kilometer more likely prone to dengue outbreaks. ${ }^{34}$ Similarly, based on the study, poverty also had positive correlation to DHF incidence.

Conferring to previous review by Maria and Gustavo, 35 major global demographic changes in parti- cular unprecedented global population growth and unplanned urbanization result substandard housing, inadequate water supply and waste management systems which are factors directly responsible for the emergence and re-emergence of DHF. Poverty is tightly connected to slum as well as lack of clean water supply.

According to Bloom and Canning, ${ }^{24}$ the quality of the environment is a determining factor of public health status. Other factors that affect public health are access to health care, heredity, and human behavior. These factors are all strongly associated with sociodemographic factors within the community. Factors that affect the incidence of DHF are not only related to the physical environmental, socioeconomic factors and culture, but also play an important role.

This study noted that in some studies, using only several indicators of sociodemographic factors may yield misleading result of relations between sociodemographic factors in general and the incidence of DHF. Other factors, such as climates, humidity, and other physical environmental as well as culture have important roles in the DHF outbreak. 36

Social and environmental factors including increasing urbanization (particularly poor population lacking of basic health services) as well as the expansion of international travel and trade are linked to the resurgence of dengue disease. Climate change may also affect disease transmission as dengue mosquitoes reproduce more readily and bite more frequently at higher temperatures. ${ }^{25,37}$ However, using all variables connected to the incidence of DHF requires cost and time of collecting data on several parameters.

There were several possible biases that could affect the study results. First, other sociodemographic factors influrncing incidence of DHF might have stronger correlation to incidence of DHF and sociodemographic correlation, such as culture, education, and area's temperature. In other words, this study probably slightly overestimated the contribution of three sociodemographic factors selected to the incidence of DHF.

The second possible limitation in this study was that the study used data from National Population Census 
2010 database. Although population census is an important source for study on trends in the composition of population and its distribution as well as a source of analysis and assessment, a change occurred in the population due to the secondary data sources used, the quantity might less synonym or not fully appropriate to answer questions of study.

\section{Conclusion}

These results suggested that poverty and density factors were important variables in affecting the incidence of DHF. Studies need to adopt a more common methodology using primary data to permit comparison. Qualified study should be encouraged to obtain more in depth, locally relevant, and descriptive data on DHF cases correlated to sociodemographic factors.

\section{Recommendation}

To prevent DHF in Indonesia, certain actions need to be taken. Because population density and poverty correlated to the DHF incidence, programs must also consider the influence of sociodemographic factors, in particular poverty and density. Efforts to eliminate DHF vectors (i.e, fogging) should be prioritized in areas where high population density and poverty problems exist, as high breeding of DHF vectors in these areas could spread the disease to other nearby areas. Laboratory-based surveillance must be developed and implemented in all endemic villages. Integrated Aedes aegypti prevention and controlled programs must be developed and implemented in synergy with public participation. Vaccines, when available, must be used for prevention as opposed to emergency response.

\section{References}

1. CDC. Dengue homepage. [Updated 2013 May; cited 2014 January]. Available from: http://www.cdc.gov/Dengue/epidemiology/.

2. Friis R. Essentials of environmental health. USA: Jones and Bartlett Publ; 2007.

3. WHO. Dengue and severe dengue [cited December 2015]. Available from: http://www.who.int/mediacentre/factsheets/fs117/en/.

4. WHO. Regional office for South-East Asia. Dengue. 2015[ Cited December 2015].Available from : http://www.searo.who.int/entity/vector_borne_tropical_diseases/data/data_factsheet/en/index1.html.

5. Prima S, Achmadi UF. Manajemen demam berdarah basis wilayah. Buletin Jendela Epidemilogi [serial on internet]. 2010 [cited 2014 Jan 5]; 2(1). Available from: www.depkes.go.id/ download?phpfile../ buletin-dbd/.

6. Kementerian kesehatan Republik Indoneisa. Combat dengue fever needs commitment from all stakeholders. Jakarta: Kementerian Kesehatan Republik Indonesia; 2012.

7. Tomashek KM, Sharp TM, Margolis HM. Infectious disease related to travel. CDC. 2015 [cited 2015 June 5]. Available from: www.cdc.gov/travel/yellowbook/2016/infectious-disease-related-to travel/dengue

8. Wahab HA, Yusof R, Rahman NA. A search for vaccines and therapeutic for dengue: a review. Current Computer -Aided Drug Design. 2007; 3 (2): 341-52.

9. Carmona A, Orozco S, Peter F, Anne P, Laura K, Eva H. A novel coding-region RNA element modulates infectious dengue virus particle production in both mammalian and mosquito, cells and regulates viral replication in Aedes aegypti mosquitos. Virologi [serian on internet]. 2012 Oct [cited 2015 Jun 5]; 432 (2): 511-26. Available from: http://www.sciencedirect.com/science/article/pii/ S004268221200 3303.

10. World Health Organization. Global strategy for dengue prevention and control. Geneva: World Health Organization; 2012 [Cited 2014 January 5]. Available from: http://apps.who.int/iris/bitstream/10665/75303/ 1/9789241504034_eng.pdf.

11. Erica R W, Paula A. Community participation in dengue prevention and control- An urban neglected tropical disease. La Prensa Medica Argentina [serial on internet]. 2009 [cited 2015 Feb 4]; 89 (3): 185-95. Available from:http://bases.bireme.br/cgi-bin/wxislind.exe/iah/online/?IsisScript=iah/iah.xis\&src=google $\&$ base $=$ LILACS\&lang=p\&next Action=lnk\&exprSearch $=561892$ \&indexSearch $=$ ID

12. World Health Organization [Home page on the internet]. Dengue in Indonesia. 2011 [cited 2013 Dec 5]. Available from: www.ino.searo.who.int.

13. Dom NC, Ahmad A, Zulkiflee AL, Rodziah I, Biswajeet. Coupling of remote sensing data and environmental-related parameters for dengue transmission risk assessment in Subang Jaya, Malaysia. Geocarto International [serial on internet]. 2013 [cited Feb 2015]; 28 (3): 258-72. Available from: http://www.tandfonline.com/doi/full/10.1080/ 10106049.2012.696726

14. Kementerian Kesehatan Republik Indonesia [homepage in the internet]. Waspada DBD di musim pancaroba. 2014 [cited 2015 January 10]. Available from: www.depkes.go.id/ article/view/5010200002/waspadadbd-di-musim-pancaroba.html.

15. Halstead SB, Nimmannitya SN. Observations related to pathogenesis of dengue hemorrhagic fever IV. Relation of disease severity to antibody response and virus recovered. Yale Journal of Biology and Medicine [serial on internet]. 1970 [2015 Feb 5]; 42 (5): 311-28. Available from: http://www.ncbi.nlm.nih.gov/pubmed/5419206.

16. Public Health Agency of Canada [homepage in the internet]. Dengue fever virus (DEN1, DEN2, DEN3, DEN4) pathogen safety data sheet. 2014 [cited 2015 Feb 4]. Available from: www.publichealth.gc.ca.

17. Chompoorsi J, Thavara U, Tawatsin A, Anantapreecha S, Siriyasatien P . Seasoning monitoring of dengue infection in aedes aegypti and serological feature of patients with suspected dengue in 4 central provinces of Thailand. The Thai Journal of Vetenary Medicine [serial on internet]. 2012 [cited 2015 Feb 5]; 42 (2): 185-93. Available from: http://www.researchgate.net/publication/230868218_Seasonal_ Monitoring_of_Dengue.

18. Sintorini M. Pengaruh iklim terhadap kasus demam berdarah dengue. Kesmas: Jurnal Kesehatan Masyarakat Nasional [serial on internet]. 2007 [cited 2015 Feb 5]; 2(1): 11-8 Available from: http://jurnalkesmas.ui.ac.id/index.php/kesmas/article/view/279/279.

19. Gubler J, Vasuden S. Dengue and dengue hemorrhagic fever. $2^{\text {nd }}$ 
Edition. UK: Oxford Shire; 2014.

20. Sumarmo. Dengue Hemorrhagic fever in Indonesia. South East Asian Journal Tropical Medicine and Public Health [serial on internet]. Sept 1987 [cited 2015 Feb 6]; 18: 269-74. Available from: http://www.ncbi.nlm.nih.gov/pubmed/3433157.

21. World Health Organization [homepage in the internet]. Dengue guidelines for diagnosis, treatment, prevention and control. Geneva: WHO; 2009 [cited 2015 Feb 6]. Available from: http://whqlibdoc.who.int/ publications/2009/9789241547871-eng.pdf.

22. Wani AA, Mejally M, Hussain WH, Al Maimani W, Hanif S, Khiujah AM. Skin rash, headache and abdominal behavior; usual presentation of intracranial hemorrhage in dengue fever. BMJ Case Report [Serial online]. 2010; 2010 [cited 2015 Feb 10]. Available from: http:// www.ncbi.nlm.nih.gov/pmc/articles/PMC3029086/.

23. Samsi TK, Wulur H, Sugianto D, Bartz CR, Tan R, Sie A. Some clinical and ideologically observations on virologically confirmed dengue hemorrhagic fever. Pediatrica Indonesiana [ serial on internet]. 1999 [cited 2015 Feb 10]; 30(2). Available from: http://europepmc.org/abstract/med/2077462.

24. Bloom D, Canning D. The Health and poverty of nations: from theory to practice. Early Human Development [serial on internet]. 2003 [Cited 2015 Feb 8]; 4(1): 47-71. Available from: http://www.tandfonline.com/doi/abs/10.1080/1464988032000051487

25. United Nation Environment Program (UNEP)[homepage on the Internet]. Better environmental management for control. [cited 2013 Jan 5]. Available from: www.who.int/heli/risks/vectors/denguecontrol/en/.

26. Beaumier C M, Gillespie P M, Peter JH. Maria EB. New vaccines for neglected parasitic diseases and dengue. Translational Research Journal. 2013; 162 (3). [cited 2015 Feb 5]. Available from: http://www. ncbi.nlm.nih.gov/pubmed/23578479.

27 Suroso T. Dengue hemorrhagic fever in Indonesia: Epidemiological Trend and Development of Control Policy. Dengue Bulletin. 1996; 2 [Cited 2015 December 10]. Available from : http://apps.who.int/ iris/bitstream/10665/147883/1/dbv20p35.pdf.

28. Kustiatuti R, Sumengen S. Prevention and control program in Indonesia. Dengue Bulletin [serial on internet]. 2005 [cited 2015 Jan 10]; 29. Available from: http://apps.who.int/iris/bitstream/10665/ 164013/1/dbv29p1.pdf.
29. Kementerain Kesehatan Republik Indonesia. Kebijakan bank data kesehatan [online]. 2015 [cited 2015 Apr 10] Available from : http://fiki2015.org/wp-content/uploads/2015/10/KEBIJAKAN-BANK-DATA1.pdf.

30. Kementerian kesehatan Republik Indonesia. Bank data per propinsi. 2015 [cited 2015 Feb 10]. Available from: http://bankdata. kemkes.go.id/.

31. Badan Pusat Statistik. Sensus penduduk tahun 2010 [online]. 2010 [cited January 2013]. Available from: http://sp2010.bps.go.id/.

32. Graham R, Jufrie M, Tan R, Hayes CG, Laksono L, Ma'Roef. A prospective sero epidemiologic studyon dengue in children four to nine years of age in Yogyakarta, Indonesia.Studies in 1995-1996. American Journal of Tropical Medicine and Hygiene [serial on internet]. 1999 [cited 2015 Feb 10]; 61: 412-9. Available from: http://www.ncbi.nlm.nih.gov/ pubmed/10497982.

33. Vaughn DW, Green S, Kalayanarooj S, Innis BL, Nimmannitya S, Suntayakorn S, et al. Dengue viremia titer, antibody response pattern, and virus serotype correlate with disease severity. Infectious Disease [serial on internet]. 2000 [cited $2015 \mathrm{Feb} 10$ ]; 181: 2-9. Available from: http://www.ncbi.nlm.nih.gov/pubmed/10608744.

34. Schmidt WP, Suzuki M, Tiem VD, White RG, Tsuzuki A, Yoshida IM. Population density water supply and the risk of dengue fever in Vietnam; cohort study and spatial analysis. Plos Med [serial on internet]. 2011 [cited 2015 Feb 10]. Available from: http://www.ncbi.nlm.nih.gove /pubmed/21918642.

35. Maria GG, Gustavo K. Dengue: an update. Lancet Infectious Disease. 2002 [cited December 2015]; 2. Available from: http://www.sciencedirect.com/science/article/pii/S1473309901001712

36. Gubler D. Dengue, urbanization, and globalization; the wholly trinity of the 21 st century. National Center for Biotechnology Information. Tropical Medicine and Health [serial on internet]. 2011 Dec [cited 2015 Oct 10]; 39 (4 Suppl): 3-11. Available from: http://www.ncbi.nlm. nih.gov/pmc/articles/ PMC3317603/.

37. Nakhapakorn K, Tripathi K. An information value based analysis of physical and climatic factors affecting dengue fever and dengue hemorrhagic fever incidence. International Journal of Health Geographics [serial on internet]. 2005 [cited $2015 \mathrm{Feb}$ 10]; 4: 13. Available from: http://www.ij-healthgeographics.com/content/4/1/13. 